\title{
Pengaruh Kompleksitas Tugas, Komitmen Organisasi, dan Time Budget Pressure Pada Perilaku Disfungsional Auditor
}

\author{
Ida Ayu Widya Krisna Dewi ${ }^{1}$ \\ I D.G. Dharma Suputra ${ }^{2}$ \\ ${ }^{1,2}$ Fakultas Ekonomi dan Bisnis Universitas Udayana (Unud), Bali, Indonesia \\ e-mail: widyakrisna20@gmail.com
}

\begin{abstract}
ABSTRAK
Tujuan penelitian ini adalah untuk menguji pengaruh perilaku disfungsional auditor yang disebabkan oleh kompleksitas tugas, komitmen organisasi, dan time budget pressure. Lokasi penelitian yaitu Perwakilan BPKP Provinsi Bali. Populasi dalam penelitian ini adalah seluruh Pejabat Fungsional Auditor yang bekerja di Perwakilan BPKP Provinsi Bali. Sampel penelitian ini dilakukan dengan teknik sampling jenuh. Data yang digunakan adalah data primer dengan teknik pengumpulan data yaitu kuesioner. Metode analisis data yang digunakan pada penelitian ini adalah analisis regresi linear berganda. Berdasarkan hasil analisis, diketahui bahwa kompleksitas tugas dan time budget pressure berpengaruh positif pada perilaku disfungsional auditor sedangkan komitmen organisasi berpengaruh negatif pada perilaku disfungsional auditor.

Kata kunci: kompleksitas tugas, komitmen organisasi, time budget pressure, perilaku disfungsional auditor
\end{abstract}

\begin{abstract}
The purpose of this study was to examine the effect of auditor dysfunctional behavior caused by task complexity, organizational commitment, and time budget pressure. The location of this study is the BPKP Representative of Bali Province. The population in this study were all Auditor Functional Officers who worked at the BPKP Representative of Bali Province. The sample of this study conducted by saturated sampling techniques. The data used are primary data with data collection technique, namely questionnaires. The data analysis methods used in this study is multiple linear regression analysis. Based on the results of analysis, it is known that task complexity and time budget pressure have a positive effect on auditor dysfunctional behavior while organizational commitment has a negative effect on auditor dysfunctional behavior.

Keywords: task complexity, organizational commitment, time budget pressure, auditor dysfunctional behavior
\end{abstract}

\section{PENDAHULUAN}

Pembangunan nasional merupakan pembangunan yang dilakukan secara berkesinambungan dan terus menerus di seluruh Indonesia yang bertujuan agar kehidupan masyarakat makmur dan adil. Pembangunan nasional yang sukses di dukung dengan pengelolaan keuangan negara yang baik agar terbebas dari praktik-praktik yang menyimpang. Peran auditor tentu sangat penting karena 
Ida Ayu Widya Krisna Dewi dan I.D.G. Dharma Suputra. Pengaruh ...

mereka harus melakukan pengawasan dengan profesional untuk mewujudkan pemerintahan yang bertanggung jawab, bersih, serta terbebas dari praktik Korupsi, Kolusi, dan Nepotisme (KKN).

Salah satu auditor internal pemerintah Indonesia adalah Badan Pengawasan Keuangan dan Pembangunan (BPKP). Menurut Peraturan Presiden (Perpres) Republik Indonesia No. 192 Tahun 2014, BPKP merupakan aparat pengawas internal pemerintah yang kedudukannya berada di bawah dan bertanggung jawab langsung kepada Presiden. Presiden memberikan kepercayaan kepada BPKP untuk melakukan evaluasi terhadap penyerapan anggaran di kementerian, lembaga, dan pemerintah daerah serta melakukan audit terhadap program-program strategis yang menjadi perhatian publik. Hasil kinerja BPKP tentu dijadikan sorotan masyarakat karena akan terlihat dari hasil audit lembaga tersebut atas akuntabilitas pemerintah. Maka dari itu, BPKP sebagai auditor internal pemerintah memiliki kewajiban untuk memberikan laporan audit yang handal, reliabel, serta transparan mengenai hasil kinerja pemerintah (Devi dan Ramantha, 2017).

Fenomena perilaku menyimpang yang dilakukan oleh auditor BPKP adalah kasus gagal audit BPKP terhadap PT Indosat Mega Media (IM2) dan PT Indosat Tbk. (ISAT). Laporan audit BPKP menyatakan adanya kerugian negara senilai Rp. 1,3 triliun dalam pembangunan jaringan frekuensi radio $2.1 \mathrm{GHz} / 3 \mathrm{G}$ oleh Indosat dan IM2 tetapi Majelis hakim menegaskan bahwa audit kerugian negara oleh BPKP dalam kasus Indosat-IM2 tidak sah. Hal ini dikarenakan pertimbangan pertama, audit tidak diawali oleh permintaan dari Kementerian Komunikasi dan 
Informatika (Kemenkominfo) sebagai regulator telekomunikasi. Kedua, tidak ditemukan adanya penggunaan frekuensi bersama Indosat-IM2 sesuai fakta-fakta persidangan dan keterangan sejumlah ahli. Ketiga, BPKP tidak pernah melakukan pemeriksaan terhadap objek audit, yakni Indosat dan anak usahanya IM2 (Okezone, 2013). Hal ini menyebabkan obyek sengketa berupa hasil audit perhitungan kerugian negara oleh BPKP mempunyai cacat hukum karena tidak pernah dilakukan audit dan tidak adanya permintaaan dari Kemenkominfo sebagai regulator sehingga melanggar beberapa pasal peraturan perundang-undangan yang berlaku (Putri, 2015).

Kasus yang sama juga terjadi di BPKP Provinsi Kalimatan Selatan pada bulan Februari 2018 lalu. Hal ini berawal dari adanya kejanggalan hasil audit BPKP Provinsi Kalimantan Selatan atas audit investigasi perhitungan kerugian keuangan negara dengan dugaan tindak pidana korupsi pembangunan delapan Ruang Kelas Baru (RKB) SMK Al Hidayah milik Yayasan At Tin Murakata di Kecamatan Haruyan, Kabupaten Hulu Sungai Tengah. Terdapat tiga kejanggalan audit BPKP Kalsel terhadap SMK Al Hidayah. Pertama, auditor BPKP Kalsel tidak pernah sekalipun turun ke lapangan untuk mencari informasi perihal proyek tersebut. Kejanggalan kedua, hasil audit BPKP Kalsel justru menemukan kerugian negara setara nilai pagu sebesar Rp. 1,7 miliar padahal tanah dan gedung dikuasai Yayasan At Tin, bukan Pemkab Hulu Sungai Tengah. Adapun kejanggalan ketiga, audit BPKP Kalsel berasumsi bahwa SMK Al Hidayah tidak bermanfaat bagi masyarakat sekitar padahal menurut tokoh Forum Masyarakat Murakata Peduli Hukum, SMK Al Hidayah sangat bermanfaat bagi putra-putri di Kecamatan 
Ida Ayu Widya Krisna Dewi dan I.D.G. Dharma Suputra. Pengaruh ...

Haruyan, Kabupaten Hulu Sungai Tengah. Sebelum BPKP Kalsel masuk mengaudit pada April 2017, BPK RI sejatinya lebih dulu menelisik proyek tersebut dan menemukan kelebihan nilai proyek sebanyak Rp. 56 juta dimana uang tersebut sudah dikembalikan dan tidak ada masalah. Itu sebabnya, masyarakat menyesalkan BPKP Kalsel kurang berhati-hati ketika menerbitkan hasil audit terhadap proyek delapan RKB di SMK Al Hidayah (Kumparan, 2018).

Fenomena yang terjadi pada Perwakilan BPKP Provinsi Bali yaitu dipertanyakannya hasil audit BPKP oleh stakeholders. Hasil audit perhitungan kerugian Negara atas kasus tindak pidana korupsi dana punia pada Institut Hindu Dharma Negeri (IHDN) Denpasar dipertanyakan oleh Penasehat Hukum dan tersangka saat persidangan. Hal ini dikarenakan hasil audit BPKP berbeda dengan hasil audit yang dilakukan oleh BPK, selain itu ahli dari BPKP yang dihadirkan di persidangan oleh Jaksa Penuntut Umum dinilai bersifat tendensius dalam memberikan keterangan sehingga kualitas audit dan kompetensi auditornya diragukan (Murtapa dan Budiartha, 2017).

Kasus ini tentu menimbulkan keraguan, apakah auditor BPKP mampu memberikan kinerja yang optimal ketika auditornya justru melakukan perilaku yang menyimpang. Hal ini menyebabkan penelitian mengenai perilaku auditor BPKP khususnya auditor Perwakilan BPKP Provinsi Bali penting untuk dilakukan. Meskipun dalam teori sudah dinyatakan secara jelas bahwa proses audit yang baik adalah audit yang mampu meningkatkan kualitas informasi yang terdapat dalam laporan audit tersebut, namun pada praktiknya masih terdapat 
auditor yang mengurangi atau mengabaikan prosedur dalam melakukan proses audit atau biasa disebut dengan perilaku disfungsional (Nehme et al., 2016).

Perilaku disfungsional auditor merupakan tindakan yang dilakukan auditor dalam pelaksanaan program audit yang dapat mereduksi atau menurunkan kualitas audit secara langsung maupun tidak langsung (Bryan et al., 2005). Malone dan Roberts (1996) menyatakan bahwa tindakan-tindakan yang dapat mereduksi kualitas audit secara langsung diantaranya adalah penghentian prosedur audit secara dini (premature sign-off) dan mengubah atau mengganti tahapan-tahapan audit (replacing or altering audit procedurs). Perilaku yang dapat mereduksi kualitas audit secara tidak langsung adalah melaporkan waktu audit lebih pendek dari waktu yang sebenarnya (underreporting of time).

Donelly et al., (2003) menyebutkan bahwa perilaku disfungsional auditor dapat dipengaruhi oleh faktor internal individu dan faktor lingkungan di luar individu. Penelitian ini berfokus pada faktor internal dan faktor eksternal yang kemungkinan dapat mempengaruhi perilaku disfungsional auditor. Faktor internal auditor dalam penelitian ini adalah komitmen organisasi sedangkan faktor eksternal yang digunakan dalam penelitian ini adalah kompleksitas tugas dan time budget pressure.

Kompleksitas tugas merupakan salah satu faktor yang mempengaruhi tinggi rendahnya perilaku disfungsional auditor. Kompleksitas tugas merupakan persepsi individu terkait dengan kesulitan tugas yang disebabkan karena terbatasnya kapasitas, daya ingat, serta kemampuan untuk mengintegrasikan masalah yang dimiliki oleh seorang pembuat keputusan (Jamilah dkk., 2007: 26). Bagi auditor 
Ida Ayu Widya Krisna Dewi dan I.D.G. Dharma Suputra. Pengaruh ...

yang mendapatkan tugas audit yang memiliki tingkat kompleksitas tugas yang tinggi, maka hal ini dapat memberikan dampak negatif pada kinerjanya. (Winanda dan Wirasedana, 2017) menjelaskan bahwa kompleksitas tugas audit yang tinggi, dapat memunculkan kesulitan dalam penyelesaian tugas audit yang kemudian akan berdampak pada kinerjanya dalam melakukan proses audit tersebut.

Faktor internal yang berhubungan dengan perilaku disfungsional auditor adalah komitmen organisasi. Komitmen organisasi yang dimiliki oleh individu diduga dapat memengaruhi perilaku disfungsional auditor dalam organisasi, hal ini disebabkan karena individu yang memiliki komitmen organisasi akan bersedia bekerja lebih keras demi kepentingan organisasi (Robbins, 2003). Individu yang memiliki komitmen organisasi yang tinggi cenderung memiliki tingkat loyalitas yang juga tinggi dan lebih bersedia melakukan pekerjaan melebihi apa yang seharusnya dikerjakan sehingga cenderung untuk berperilaku fungsional (Mindarti dan Elen, 2014). Tingginya tingkat loyalitas inilah yang akan mengakibatkan individu cenderung menolak perilaku disfungsional dibandingkan dengan individu yang memiliki komitmen organisasi yang rendah.

Selain karakteristik individual yang merupakan faktor internal auditor dalam melakukan penerimaan terhadap perilaku disfungsional auditor, terdapat juga faktor eksternal lainnya yaitu time budget pressure yang diindikasikan turut memengaruhi auditor dalam menerima perilaku disfungsional tersebut. Time budget pressure merupakan suatu keadaan ketika auditor dituntut untuk melakukan efisiensi terhadap anggaran waktu yang telah ditetapkan (Margheim dan Kelley, 2005). Auditor yang terjebak antara pemenuhan tugas audit dan 
kendala alokasi waktu akan mengalami dilema (Cook dan Kelley, 1988). Tekanan ini dapat menyebabkan auditor melakukan perilaku disfungsional seperti melewati beberapa proses audit untuk meminimalisir waktu penugasan auditnya.

Hasil penelitian - penelitian sebelumnya menjelaskan adanya ketidakkonsistenan yang dilakukan oleh peneliti sebelumnya. Penelitian yang dilakukan oleh Restuningdiah dan Indriantoro (2000), Prasita dan Priyo (2007), Mustikayani (2016) serta Winanda dan Wirasedana (2017) mendukung bahwa variabel kompleksitas tugas berpengaruh positif terhadap perilaku disfungsional audit. Tetapi hasil berbeda diungkapkan oleh Malone dan Roberts (1996) serta Umar et al., (2017) yang menyatakan bahwa kompleksitas tugas audit tidak berpengaruh terhadap perilaku audit disfungsional.

Penelitian Otley dan Pierce (1996), Yolanda (2014), Anugerah et al., (2016) Limawan dan Mimba (2016) serta Grahita dan Sukirman (2017) menunjukkan hasil bahwa komitmen organisasi berpengaruh negatif terhadap perilaku audit disfungsional. Berbeda dengan penelitian Srimindarti (2012) dan Donelly et al., (2003) yang menyatakan komitmen organisasi tidak berpengaruh pada penerimaan perilaku disfungsional auditor.

Hasil penelitian yang dilakukan oleh DeZoort dan Lord (1997), Aini (2015), Dewi dan Wirasedana (2015), Svanström (2016), serta Devi dan Ramantha (2017) menunjukkan hasil bahwa time budget pressure berpengaruh positif pada perilaku disfungsional auditor. Tetapi hasil berbeda diungkapkan oleh Zuhra (2009) yang menyimpulkan bahwa time budget pressure tidak berpengaruh terhadap perilaku disfungsional audit. 
Ida Ayu Widya Krisna Dewi dan I.D.G. Dharma Suputra. Pengaruh ...

Penelitian ini menggunakan variabel independen kompleksitas tugas, komitmen organisasi, dan time budget pressure dengan dasar pertimbangan yaitu ketidakkonsistenan dari hasil penelitian sebelumnya. Populasi pada penelitian ini adalah auditor internal pemerintah yang bekerja di Perwakilan BPKP Provinsi Bali. Alasan peneliti menggunakan populasi yang berfokus pada auditor internal pemerintah yang bekerja di Perwakilan BPKP Provinsi Bali adalah tuntutan atas peran auditor internal pemerintah untuk menghasilkan laporan audit yang berkualitas, sehingga Perwakilan BPKP Provinsi Bali dengan posisinya sebagai auditor internal pemerintah Provinsi Bali memiliki peranan penting untuk menciptakan akuntabilitas aparat pemerintahan untuk mewujudkan pemerintahan yang bersih dan terbebas dari praktik KKN.

Tujuan dari penelitian ini adalah untuk menguji pengaruh kompleksitas tugas pada perilaku disfungsional auditor, pengaruh komitmen organisasi pada perilaku disfungsional auditor, dan pengaruh time budget pressure pada perilaku disfungsional auditor. Manfaat penelitian ini secara teoritis adalah memberikan tambahan informasi dan memperkaya literatur akuntansi, khususnya yang berkaitan dengan faktor-faktor yang memengaruhi perilaku disfungsional auditor serta dapat membuktikan teori yang digunakan yaitu Teori Atribusi yang menjelaskan bahwa perilaku seseorang disebabkan oleh faktor internal dan faktor eksternal. Hasil penelitian ini juga dapat memberikan bukti empiris mengenai pengaruh kompleksitas tugas, komitmen organisasi, dan time budget pressure pada perilaku disfungsional auditor. Sedangkan manfaat praktis penelitian ini adalah memberikan gambaran nyata tentang perilaku disfungsional auditor 
sehingga para auditor Perwakilan BPKP Provinsi Bali dapat merencanakan prosedur dan penugasan audit dengan lebih terstruktur dan matang pada tugas audit berikutnya. Selanjutnya digunakan sebagai bahan evaluasi demi

Teori atribusi merupakan teori yang menjelaskan tentang perilaku seseorang. Teori ini dicetuskan oleh Fritz Heider pada tahun 1958. Teori atribusi mempelajari proses bagaimana seseorang menginterpretasikan suatu peristiwa, mempelajari bagaimana seseorang menginterpretasikan alasan atau sebab perilakunya (Surya et al., 2017). Menurut Dougall (1999), faktor - faktor yang memengaruhi perilaku seseorang adalah faktor personal yaitu faktor yang berasal dari dalam individu yang meliputi faktor biologi manusia, faktor sosiopsikologis, dan motif sosiogenis serta faktor situasional yaitu faktor yang berasal dari luar diri individu meliputi aspek objektif lingkungan, lingkungan psikososial yang dipersepsi seseorang.

Perilaku disfungsional auditor adalah setiap tindakan yang dilakukan auditor selama pelaksanakan program audit yang dapat mereduksi kualitas audit baik secara langsung maupun tidak langsung (Otley dan Pierce, 1996). Perilakuperilaku yang mereduksi kualitas audit dilakukan melalui tindakan seperti replacing or altering audit procedurs, underreporting of time, dan premature sign-off. Tindakan penggantian prosedur audit (altering of audit procedure) dilakukan karena auditor berpendapat bahwa prosedur yang telah ditetapkan memerlukan waktu yang lama untuk diterapkan sehingga auditor melakukan penggantian prosedur audit sesuai dengan kehendaknya. Perilaku auditor melaporkan waktu lebih pendek dari waku aktual yang digunakan untuk 
Ida Ayu Widya Krisna Dewi dan I.D.G. Dharma Suputra. Pengaruh ...

menyelesaikan tugas audit tertentu disebut dengan underreporting of time. Tindakan ini berhubungan tidak langsung dengan penurunan kualitas audit, walaupun auditor melaksanakan semua tahapan program audit, perilaku underreporting of time dapat mengakibatkan manajemen mengambil keputusan tidak relevan berkaitan dengan penetapan waktu pemeriksaan penugasan tahun berikutnya (Kustinah, 2013). Premature sign-off merupakan suatu keadaan yang menunjukkan auditor menghentikan satu atau beberapa langkah audit yang diperlukan dalam prosedur audit tanpa menggantikan dengan langkah yang lain (Devi dan Ramantha, 2017).

Kompleksitas tugas merupakan sikap yang dimiliki oleh individu karena kemampuan serta daya ingat untuk melaksanakan sebuah tugas audit (Jamilah dkk., 2007). Dalam melaksanakan tugas audit banyak dihadapi oleh persoalan yang kompleks. Kesulitan yang dirasakan oleh setiap individu berbeda-beda biasanya terjadi ketidakkonsistenan petunjuk informasi dan tidak mampu dalam mengambil suatu keputusan akan menjadikan sebuah tugas semakin kompleks. Ketika tugas semakin kompleks dan tidak terstruktur, usaha yang tinggi tidak akan membantu seorang auditor untuk menyelesaikan tugas tersebut. Hal ini berarti semakin kompleks tugas audit maka perilaku disfungsional auditor dalam kegiatan auditnya akan semakin meningkat.

Penelitian yang dilakukan oleh Restuningdiah dan Indriantoro (2000), Prasita dan Priyo (2007), Mustikayani (2016), serta Winanda dan Wirasedana (2017) menemukan hasil bahwa kompleksitas tugas berpengaruh positif terhadap 
perilaku disfungsional auditor. Berdasarkan penelitian tersebut, maka hipotesis penelitian yang dirumuskan sebagai berikut.

$\mathrm{H}_{1}$ : Kompleksitas tugas berpengaruh positif pada perilaku disfungsional auditor.

Komitmen organisasi merupakan tingkat penerimaan individu terhadap tujuan organisasi dan kesediaan untuk mencapai tujuan organisasi tersebut (Donelly et al., 2003). Karakteristik dari komitmen organisasi menurut Porter et al., (1974) yaitu: (1) kepercayaan dan penerimaan akan tujuan dan nilai-nilai organisasi, (2) kemauan untuk mengusahakan tercapainya tujuan organisasi, dan (3) keinginan yang kuat untuk mempertahankan diri dalam organisasi. Semakin kuat komitmen organisasi individu maka tingkat loyalitasnya juga semakin baik karena mereka yakin dengan tujuan dan nilai-nilai organisasi. Tingginya tingkat loyalitas ini akan mengakibatkan individu tersebut cenderung menolak perilaku disfungsional. Sebaliknya, individu dengan komitmen organisasi yang rendah akan memiliki keinginan untuk lebih berfokus pada kepentingan pribadi daripada kepentingan organisasi sehingga cenderung untuk berperilaku disfungsional.

Penelitian yang dilakukan Otley dan Pierce (1996), Yolanda (2014), Anugerah et al., (2016), Limawan dan Mimba (2016), serta Grahita dan Sukirman (2017) menyatakan bahwa komitmen organisasi berpengaruh negatif pada perilaku disfungsional audit. Berdasarkan penelitian tersebut, maka hipotesis penelitian yang dirumuskan sebagai berikut.

$\mathrm{H}_{2}$ : Komitmen organisasi berpengaruh negatif pada perilaku disfungsional auditor.

Time budget atau anggaran waktu sangat penting untuk dipenuhi oleh auditor dalam memenuhi permintaan klien agar dapat menyelesaikan 
Ida Ayu Widya Krisna Dewi dan I.D.G. Dharma Suputra. Pengaruh ...

pekerjaannya dengan tepat waktu (Ervinayanti, 2013). Terbatasnya alokasi waktu dalam pelaksanaan tugas ditambah dengan adanya kesadaran bahwa anggaran waktu digunakan sebagai tolok ukur kinerjanya, menyebabkan stress individual bagi para auditor (Svanström, 2016). Anggaran waktu yang ketat mengakibatkan auditor tidak dapat menyelesaikan seluruh prosedur audit yang seharusnya dilakukan karena tekanan yang diberikan oleh atasan dianggap mustahil untuk dipenuhi oleh auditor. Hal ini akan berakibat pada perilaku disfungsional audit untuk memenuhi anggaran waktu yang diberikan. Hal ini berarti semakin ketat tekanan anggaran waktu yang dirasakan oleh auditor, maka semakin tinggi potensi terjadinya perilaku disfungsional auditor.

Penelitian DeZoort dan Lord (1997), Dewi dan Wirasedana (2015), Aini (2015), Svanström (2016), serta Devi dan Ramantha (2017) menunjukkan bahwa tekanan anggaran waktu berpengaruh positif pada penerimaan perilaku disfungsional audit. Berdasarkan penelitian tersebut, maka hipotesis penelitian yang dirumuskan sebagai berikut.

$\mathrm{H}_{3}$ : Time budget pressure berpengaruh positif pada perilaku disfungsional auditor.

\section{METODE PENELITIAN}

Penelitian ini dilakukan di Perwakilan BPKP Provinsi Bali yang beralamat di Jalan Kapten Tantular, Denpasar, Bali. Pada penelitian ini, obyek penelitiannya yaitu Pejabat Fungsional Auditor (PFA) di Perwakilan BPKP Provinsi Bali yang dipengaruhi oleh kompleksitas tugas, komitmen organisasi, dan time budget pressure. 
Populasi dalam penelitian ini adalah seluruh Pejabat Fungsional Auditor (PFA) yang bekerja di Perwakilan BPKP Provinsi Bali. Jumlah populasi dalam penelitian ini yaitu 74 auditor. Banyaknya sampel yang diambil pada penelitian ini berjumlah 74 auditor.

Metode analisis data yang digunakan dalam penelitian ini adalah teknik analisis regresi linier berganda. Analisis regresi linear berganda merupakan teknik untuk mengetahui pengaruh dua atau lebih variabel independen dengan variabel dependen apakah masing-masing variabel independen berhubungan positif atau negatif dan untuk memprediksi nilai dari variabel dependen apabila nilai variabel independen mengalami kenaikan atau penurunan (Sugiyono, 2016:275). Model regresi dalam penelitian ini ditunjukkan dengan persamaan sebagai berikut.

$$
\mathrm{Y}=\alpha+\beta_{1} \mathrm{X}_{1}+\beta_{2} \mathrm{X}_{2}+\beta_{3} \mathrm{X}_{3}+\mathrm{e}
$$

\section{Keterangan:}

$\mathrm{Y}=$ perilaku disfungsional auditor

$\alpha \quad=$ konstanta

$\mathrm{X}_{1} \quad=$ kompleksitas tugas

$\mathrm{X}_{2} \quad=$ komitmen organisasi

$\mathrm{X}_{3} \quad=$ time budget pressure

$\beta 1, \beta 2, \beta 3=$ koefisien regresi parsial

$$
\mathrm{e}=\text { error }
$$

\section{HASIL DAN PEMBAHASAN}

Karakteristik responden merupakan profil 53 responden yang berpartisipasi dalam pengisian kuesioner. Hal ini ditujukan untuk menjelaskan latar belakang responden yang menjadi sampel dalam penelitian ini. Data profil responden dapat dilihat pada Tabel 1 . 
Tabel 1.

Karakteristik Responden

\begin{tabular}{|c|c|c|c|c|}
\hline No. & Kriteria & Keterangan & $\begin{array}{l}\text { Jumlah } \\
\text { (orang) }\end{array}$ & $\begin{array}{c}\text { Persentase } \\
(\%)\end{array}$ \\
\hline \multirow{5}{*}{1.} & \multirow{2}{*}{ Jenis Kelamin } & Laki-laki & 35 & 66,04 \\
\hline & & Perempuan & 18 & 33,96 \\
\hline & \multirow{7}{*}{ Jabatan Auditor } & lah & 53 & 100 \\
\hline & & Pelaksana & 10 & 18,87 \\
\hline & & Pelaksana Lanjutan & 7 & 13,21 \\
\hline \multirow{6}{*}{2.} & & Penyelia & 12 & 22,64 \\
\hline & & Pertama & 8 & 15,10 \\
\hline & & Muda & 11 & 20,75 \\
\hline & & Madya & 5 & 9,43 \\
\hline & \multicolumn{2}{|c|}{ Jumlah } & 53 & 100 \\
\hline & \multirow{4}{*}{ Pendidikan Terakhir } & S3 & 0 & 0 \\
\hline \multirow{4}{*}{3.} & & S2 & 1 & 1,89 \\
\hline & & S1 / Diploma IV & 35 & 66,04 \\
\hline & & Diploma III & 17 & 32,07 \\
\hline & \multirow{4}{*}{ Lama Bekerja } & & 53 & 100 \\
\hline \multirow{3}{*}{4.} & & $<5$ tahun & 11 & 20,75 \\
\hline & & $\geq 5$ tahun & 42 & 79,25 \\
\hline & & lah & 53 & 100 \\
\hline
\end{tabular}

Sumber: Data diolah, 2018

Karakteristik responden berdasarkan jenis kelamin menjelaskan mengenai proporsi auditor laki-laki dan perempuan. Tabel 1 menunjukkan bahwa mayoritas responden adalah laki-laki.

Karakteristik responden berdasarkan jabatan auditor untuk mengetahui kedudukan dan tanggung jawab responden di instansi tersebut. Tabel 1 menunjukkan bahwa mayoritas responden dengan jabatan sebagai auditor penyelia.

Karakteristik responden berdasarkan pendidikan terakhir untuk mengetahui pemahaman dan tingkat intelektual responden. Tabel 1 menunjukkan bahwa mayoritas responden adalah responden dengan tingkat pendidikan S1/Diploma IV.

Karakteristik responden berdasarkan lama waktu bekerja untuk mengetahui lamanya pengalaman audit yang dimiliki auditor bekerja di instansi tersebut. 
Tabel 1 menunjukkan bahwa mayoritas responden telah bekerja selama lebih atau sama dengan 5 tahun.

Analisis statistik deskriptif digunakan untuk menggambarkan atau menjelaskan suatu data pada variabel penelitian terkait dengan nilai minimum, nilai maksimum, nilai rata-rata (mean), dan standar deviasi.

Tabel 2.

Hasil Analisis Statistik Deskriptif

\begin{tabular}{cccccc}
\hline Variabel & N & Min. & Max. & Mean & Std. Deviasi \\
\hline Kompleksitas Tugas & 53 & 12 & 23 & 19,21 & 2,169 \\
Komitmen Organisasi & 53 & 20 & 35 & 29,06 & 3,189 \\
Time Budget Pressure & 53 & 18 & 30 & 26,42 & 3,035 \\
Perilaku Disfungsional Auditor & 53 & 24 & 43 & 38,51 & 4,689 \\
\hline Sumber: Data diolah, 2018 & & & &
\end{tabular}

Berdasarkan Tabel 2 dapat disimpulkan bahwa jumlah pengamatan $(\mathrm{N})$ penelitian ini berjumlah 53. Variabel kompleksitas tugas memiliki nilai minimum sebesar 12 dan nilai maksimum sebesar 23 dengan nilai rata-rata sebesar 19,21. Nilai rata-rata sebesar 19,21 menunjukkan bahwa respon responden dalam menjawab pernyataan pada kuesioner cenderung merasa setuju pada masingmasing item pernyataan artinya kompleksitas tugas cenderung tinggi, yang berarti responden mengalami tugas yang kompleks dalam pelaksanaan audit. Standar deviasi pada variabel kompleksitas tugas adalah sebesar 2,169. Hal ini menunjukkan bahwa standar penyimpangan data terhadap nilai rata-ratanya adalah 2,169.

Variabel komitmen organisasi memiliki nilai minimum sebesar 20 dan nilai maksimum sebesar 35 dengan nilai rata-rata sebesar 29,06. Nilai rata-rata sebesar 29,06 menunjukkan bahwa respon responden dalam menjawab pernyataan pada kuesioner cenderung merasa setuju pada masing-masing item pernyataan 
Ida Ayu Widya Krisna Dewi dan I.D.G. Dharma Suputra. Pengaruh ...

artinya komitmen organisasi cenderung tinggi, yang berarti responden memiliki komitmen terhadap organisasi tempat mereka bekerja. Standar deviasi pada variabel kompleksitas tugas adalah sebesar 3,189. Hal ini menunjukkan bahwa standar penyimpangan data terhadap nilai rata-ratanya adalah 3,189 .

Variabel time budget pressure memiliki nilai minimum sebesar 18 dan nilai maksimum sebesar 30 dengan nilai rata-rata sebesar 26,42 . Nilai rata-rata sebesar 26,42 menunjukkan bahwa respon responden dalam menjawab pernyataan pada kuesioner cenderung merasa setuju pada masing-masing item pernyataan artinya time budget pressure cenderung tinggi, yang berarti responden mengalami time budget pressure dalam pelaksanaan audit. Standar deviasi pada variabel time budget pressure adalah sebesar 3,035. Hal ini menunjukkan bahwa standar penyimpangan data terhadap nilai rata-ratanya adalah 3,035.

Variabel perilaku disfungional auditor memiliki nilai minimum sebesar 24 dan nilai maksimum sebesar 43 dengan nilai rata-rata sebesar 38,51. Nilai ratarata sebesar 38,51 menunjukkan bahwa respon responden dalam menjawab pernyataan pada kuesioner cenderung merasa setuju pada masing-masing item pernyataan artinya perilaku disfungional auditor cenderung tinggi, yang berarti responden cenderung melakukan peningkatan perilaku disfungional auditor dalam pelaksanaan audit. Standar deviasi pada variabel perilaku disfungional auditor adalah sebesar 4,689. Hal ini menunjukkan bahwa standar penyimpangan data terhadap nilai rata-ratanya adalah 4,689.

Hasil analisis regresi linear berganda menunjukan seberapa besar nilai signifikansi dari seluruh variabel bebas berpengaruh terhadap variabel terikat. 
Hasil analisis dinyatakan dalam bentuk persamaan regresi linear berganda pada Tabel 3 sebagai berikut.

Tabel 3.

Hasil Analisis Regresi Linear Berganda

\begin{tabular}{|c|c|c|c|c|c|}
\hline \multirow[t]{2}{*}{ Variabel } & \multicolumn{2}{|c|}{$\begin{array}{c}\text { Unstandardized } \\
\text { Coefficients }\end{array}$} & \multirow{2}{*}{$\begin{array}{c}\text { Standardized } \\
\text { Coefficients } \\
\text { Beta }\end{array}$} & \multirow[t]{2}{*}{$\mathrm{t}$} & \multirow[t]{2}{*}{ Sig. } \\
\hline & $\mathrm{B}$ & Std. Error & & & \\
\hline Constant & 2,341 & 2,811 & & 0,833 & 0,409 \\
\hline Kompleksitas Tugas & 0,862 & 0,205 & 0,399 & 4,200 & 0,000 \\
\hline Komitmen Organisasi & $-0,334$ & 0,133 & $-0,227$ & $-2,505$ & 0,016 \\
\hline Time Budget Pressure & 1,100 & 0,140 & 0,712 & 7,850 & 0,000 \\
\hline Adjusted $R$ Square & & & 0,759 & & \\
\hline F Hitung & & & 55,665 & & \\
\hline Signifikansi F & & & 0,000 & & \\
\hline
\end{tabular}

Sumber: Data diolah, 2018

Berdasarkan Tabel 3 dapat disusun persamaan regresi linear berganda sebagai berikut.

$$
\mathrm{Y}=2,341+0,862 \mathrm{X}_{1}-0,334 \mathrm{X}_{2}+1,100 \mathrm{X}_{3}
$$

Konstanta regresi $(\alpha)$ sebesar 2,341 menunjukan bahwa apabila nilai kompleksitas tugas $\left(\mathrm{X}_{1}\right)$, komitmen organisasi $\left(\mathrm{X}_{2}\right)$, dan time budget pressure $\left(\mathrm{X}_{3}\right)$ sama dengan nol, maka nilai perilaku disfungsional auditor (Y) meningkat sebesar 2,341 satuan.

Koefisien regresi kompleksitas tugas $\left(\beta_{1}\right)$ sebesar 0,862 menunjukan bahwa variabel kompleksitas tugas mempunyai hubungan positif pada perilaku disfungsional auditor. Artinya, setiap kenaikan 1 satuan variabel kompleksitas tugas dengan asumsi variabel komitmen organisasi dan time budget pressure konstan, maka akan meningkatkan perilaku disfungsional auditor sebesar 0,862 satuan.

Koefisien regresi komitmen organisasi $\left(\beta_{2}\right)$ sebesar $-0,334$ menunjukan bahwa variabel komitmen organisasi mempunyai hubungan negatif pada perilaku 
Ida Ayu Widya Krisna Dewi dan I.D.G. Dharma Suputra. Pengaruh ...

disfungsional auditor. Artinya, setiap kenaikan 1 satuan variabel komitmen organisasi dengan asumsi variabel kompleksitas tugas dan time budget pressure konstan, maka akan menurunkan perilaku disfungsional auditor sebesar 0,334 satuan.

Koefisien regresi time budget pressure $\left(\beta_{3}\right)$ sebesar 1,100 menunjukan bahwa variabel time budget pressure mempunyai hubungan positif pada perilaku disfungsional auditor. Artinya, setiap kenaikan 1 satuan variabel time budget pressure dengan asumsi variabel kompleksitas tugas dan komitmen organisasi konstan, maka akan meningkatkan perilaku disfungsional auditor sebesar 1,100 satuan.

Berdasarkan nilai adj. $\mathrm{R}^{2}$ dapat diketahui berapa persen variabel dependen dapat dijelaskan oleh variabel independen, sedangkan sisanya dipengaruhi atau dijelaskan oleh variabel lain yang tidak dimasukkan dalam model penelitian. Berdasarkan Tabel 3 nilai adjusted $R^{2}$ sebesar 0,759 , hal ini berarti 75,9\% variasi perilaku disfungsional auditor dipengaruhi oleh variasi kompleksitas tugas $\left(\mathrm{X}_{1}\right)$, komitmen organisasi $\left(\mathrm{X}_{2}\right)$, dan time budget pressure $\left(\mathrm{X}_{3}\right)$ serta sisanya sebesar 24,1\% dipengaruhi oleh variabel lain di luar model penelitian.

Berdasarkan Tabel 3 variabel bebas berpengaruh serempak (simultan) terhadap variabel terikat. Nilai signifikansi F pada tabel sebesar 0,000 yang lebih kecil dari 0,05 . Hal ini menunjukan bahwa model regresi linear berganda layak digunakan sebagai alat analisis untuk menguji pengaruh variabel bebas pada variabel terikat. Ini berarti, seluruh variabel bebas (kompleksitas tugas, komitmen 
organisasi, dan time budget pressure) dapat memprediksi atau menjelaskan fenomena perilaku disfungsional auditor pada Perwakilan BPKP Provinsi Bali.

Berdasarkan hasil pengujian pada Tabel 3 diketahui bahwa nilai $\beta_{1}=0,862$ dengan tingkat signifikansi sebesar 0,000 lebih kecil dari $\alpha=0,05$. Hal ini memiliki arti bahwa variabel kompleksitas tugas berpengaruh positif pada perilaku disfungsional auditor. Hal ini menerima hipotesis pertama $\left(\mathrm{H}_{1}\right)$ yang menyatakan bahwa kompleksitas tugas berpengaruh positif pada perilaku disfungsional auditor.

Berdasarkan teori atribusi dijelaskan bahwa perilaku seseorang ditentukan oleh kombinasi faktor internal dan eksternal. Faktor internal dapat berupa pengetahuan dan kemampuan auditor dan faktor eksternal seperti tekanan ketaatan dan kompleksitas tugas yang dihadapi. Auditor yang mengalami kompleksitas tugas yang tinggi akan meningkatkan perilaku disfungsional auditor, sebaliknya apabila tingkat kompleksitas tugas yang dialami auditor rendah maka perilaku disfungsional auditor juga akan semakin menurun. Kondisi ini menggambarkan bahwa peningkatan kompleksitas dalam suatu tugas atau sistem, akan menurunkan tingkat keberhasilan tugas itu. Terkait dengan kegiatan pengauditan, tingginya kompleksitas audit ini bisa menyebabkan akuntan berperilaku disfungsional sehingga menyebabkan penurunan kualitas audit. Hasil penelitian ini konsisten dengan penelitian Restuningdiah dan Indriantoro (2000), Prasita dan Priyo (2007), Mustikayani (2016), serta Winanda dan Wirasedana (2017) yang menyatakan bahwa kompleksitas tugas berpengaruh terhadap perilaku disfungsional. 
Ida Ayu Widya Krisna Dewi dan I.D.G. Dharma Suputra. Pengaruh ...

Berdasarkan hasil pengujian pada Tabel 3 diketahui bahwa nilai $\beta_{2}=-0,334$ dengan tingkat signifikansi sebesar 0,016 lebih kecil dari $\alpha=0,05$. Hal ini memiliki arti bahwa variabel komitmen organisasi berpengaruh negatif pada perilaku disfungsional auditor. Hal ini menerima hipotesis kedua $\left(\mathrm{H}_{2}\right)$ yang menyatakan bahwa komitmen organisasi berpengaruh negatif pada perilaku disfungsional auditor. Auditor yang memiliki komitmen organisasi yang tinggi akan menjalankan program audit sesuai prosedur yang ada dan akan berperilaku fungsional dalam menjalankan tugas auditnya. Sebaliknya, apabila seorang auditor tidak memiliki komitmen organisasi maka berindikasi pada meningkatnya perilaku disfungsional auditor.

Mengacu pada teori atribusi bahwa suatu individu dapat bertindak menurut karakter personalitas mereka. Individu yang mempunyai komitmen yang tinggi pada organisasi, akan bersedia untuk bekerja keras dan akan mempunyai kinerja yang lebih baik (Baron dan Greenberg, 1990). Semakin tinggi komitmen organisasi individu maka tingkat loyalitasnya juga semakin baik karena mereka yakin dengan tujuan dan nilai-nilai organisasi. Tingginya tingkat loyalitas ini akan mengakibatkan individu tersebut cenderung menolak perilaku disfungsional. Sebaliknya, individu dengan komitmen organisasi yang rendah akan memiliki keinginan untuk lebih berfokus pada kepentingan pribadi daripada kepentingan organisasi sehingga cenderung untuk berperilaku disfungsional. Hasil penelitian ini sejalan dengan penelitian yang dilakukan oleh Otley dan Pierce (1996), Yolanda (2014), Anugerah et al., (2016), Limawan dan Mimba (2016), serta 
Grahita dan Sukirman (2017) yang menyatakan bahwa komitmen organisasi berpengaruh negatif pada perilaku disfungsional auditor.

Berdasarkan hasil pengujian pada Tabel 3 diketahui bahwa nilai $\beta_{3}=1,100$ dengan tingkat signifikansi sebesar 0,000 lebih kecil dari $\alpha=0,05$. Hal ini memiliki arti bahwa variabel time budget pressure berpengaruh positif pada perilaku disfungsional auditor. Hal ini menerima hipotesis ketiga $\left(\mathrm{H}_{3}\right)$ yang menyatakan bahwa time budget pressure berpengaruh positif pada perilaku disfungsional auditor. Auditor yang mengalami time budget pressure yang tinggi akan meningkatkan perilaku disfungsional auditor, sebaliknya apabila tingkat time budget pressure yang dialami auditor rendah maka perilaku disfungsional auditor juga akan semakin menurun.

Berdasarkan teori atribusi dijelaskan bahwa seseorang dalam berperilaku ditentukan oleh faktor internal dan faktor eksternal. Salah satu faktor eksternal yang memicu perilaku seseorang adalah time budget pressure. Hal ini dikarenakan jika time budget audit dibatasi sedemikian rupa, maka auditor akan kerepotan dalam melakukan pekerjaannya sedangkan hasil audit auditor diharapkan sesuai dengan standar padahal time budget audit terbatas. Tekanan tersebut menyebabkan auditor melakukan perilaku tertentu untuk mencapai tujuannya termasuk perilaku disfungsional auditor. Penelitian ini memperkuat pendapat bahwa auditor terlibat perilaku disfungsional auditor (premature sign-off, underreporting of time, altering or replacing of audit procedures) terjadi pada situasi saat auditor memandang diri mereka kurang mampu untuk mencapai outcome yang diharapkan akibat tekanan yang diberikan oleh atasan. Hasil 
Ida Ayu Widya Krisna Dewi dan I.D.G. Dharma Suputra. Pengaruh ...

penelitian ini konsisten dengan hasil penelitian sebelumnya yang menyatakan bahwa auditor menerima time budget pressure sebagai penyebab perilaku disfungsional auditor antara lain DeZoort dan Lord (1997), Dewi dan Wirasedana (2015), Aini (2015), Svanström (2016), serta Devi dan Ramantha (2017).

Hasil penelitian ini memberikan tambahan informasi mengenai bagaimana kompleksitas tugas, komitmen organisasi, dan time budget pressure memengaruhi perilaku disfungsional auditor. Terdapat bukti empiris yang diperoleh melalui penelitian ini yang menunjukkan bahwa kompleksitas tugas, komitmen organisasi, dan time budget pressure berpengaruh pada perilaku disfungsional auditor. Hal ini menunjukkan bahwa semakin tinggi kompleksitas tugas dan time budget pressure seorang auditor maka semakin meningkat pula perilaku disfungsional auditor sedangkan semakin tinggi komitmen organisasi seorang auditor maka semakin menurun perilaku disfungsional auditor. Hal ini didukung dengan adanya teori atribusi yang menyebutkan bahwa perilaku disfungsional auditor disebabkan oleh faktor internal dan faktor eksternal.

Hasil penelitian ini dapat memberikan kontribusi positif khususnya Perwakilan BPKP Provinsi Bali dalam mengurangi adanya perilaku disfungsional auditor. Penelitian ini juga menjelaskan bahwa komitmen organisasi yang tinggi akan menurunkan perilaku disfungsional auditor sedangkan tingginya kompleksitas tugas dan time budget pressure berdampak pada meningkatnya perilaku disfungsional auditor sehingga diharapkan akan tercipta solusi yang dapat membantu auditor untuk mengatasi hal ini agar auditor di Perwakilan BPKP Provinsi Bali bisa tetap mempertahankan profesionalismenya dalam melakukan 
penugasan audit serta menurunkan perilaku disfungsional guna meningkatkan kualitas audit.

\section{SIMPULAN}

Kompleksitas tugas berpengaruh positif pada perilaku disfungsional auditor di Perwakilan BPKP Provinsi Bali. Hal ini berarti semakin tinggi kompleksitas tugas seorang auditor, maka perilaku disfungsional auditor cenderung meningkat.

Komitmen organisasi berpengaruh negatif pada perilaku disfungsional auditor di Perwakilan BPKP Provinsi Bali. Hal ini berarti semakin tinggi komitmen organisasi seorang auditor, maka perilaku disfungsional auditor cenderung menurun.

Time budget pressure berpengaruh positif pada perilaku disfungsional auditor di Perwakilan BPKP Provinsi Bali. Hal ini berarti semakin tinggi time budget pressure seorang auditor, maka perilaku disfungsional auditor cenderung meningkat.

Pada kompleksitas tugas, indikator kesulitan tugas yaitu ketidakjelasan tugas yang harus dikerjakan mendapatkan skor rata-rata terendah. Maka auditor disarankan untuk membentuk sebuah diskusi antar anggota tim audit untuk lebih memperjelas tugas yang harus dikerjakan sebelum tim audit melaksanakan tugasnya.

Pada komitmen organisasi, indikator komitmen afektif yaitu kesulitan merasa terikat dengan organisasi mendapatkan skor rata-rata terendah. Maka 
Ida Ayu Widya Krisna Dewi dan I.D.G. Dharma Suputra. Pengaruh ...

auditor disarankan untuk meningkatkan rasa komitmen organisasi yang dimilikinya.

Pada time budget pressure, indikator ketercapaian anggaran yaitu ketidakmampuan memenuhi target dengan anggaran waktu yang telah ditentukan mendapatkan skor rata-rata terendah. Maka auditor disarankan untuk memperhatikan penyusunan time budget yang memadai.

Pada perilaku disfungsional auditor, indikator premature sign-off yaitu tidak diperlukannya prosedur audit mendapatkan skor rata-rata terendah. Maka disarankan kepada Kepala Perwakilan BPKP Provinsi Bali untuk mengawasi dan mengevaluasi auditor dalam melakukan penugasan audit agar semua prosedur audit dilaksanakan dengan baik.

Bagi peneliti selanjutnya, penelitian ini dapat menjadi referensi bagi yang tertarik melakukan penelitian sejenis dan disarankan menggunakan variabel lain yang tidak digunakan dalam penelitian ini. Penggunaan objek penelitian yang berbeda juga dapat dilakukan seperti Badan Pemeriksa Keuangan, Inspektorat, ataupun Kantor Akuntan Publik.

\section{REFERENSI}

Aini, F. A. N. (2015). Pengaruh Tekanan Waktu, Tindakan Supervisi, Locus of Control Terhadap Penghentian Prematur. Jurnal Ilmu dan Riset Akuntansi, 4(3), 1-18.

Anugerah, R., Anita, R., Sari, R. N., Abdillah, Rasyid, M., Moh, Iskandar. (2016). The Analysis of Reduced Audit Quality Behavior: The Intervening Role of Turnover Intention. International Journal of Economics and Management, 10(2), 341-353. 
Baron, R.A., \& Greenberg, J. (1990). Behavior in Organizations: Understanding and Managing The Human Side of Work (3rd Edition). Boston: Allyn and Bacon.

Bryan, D., J.Jeffrey Quirin, D. P. D. (2005). Locus of Control and Dysfunctional Audit Behavior. Journal of Business \& Economic Research, 3(10).

Cook, E., \& Kelley, T. (1988). Management of Accounting Practices: Auditor Stress and Time Budget. The CPA Journal, 58(7), 83-86.

Devi, N. . A., \& Ramantha, I. W. (2017). Tekanan Anggaran Waktu, Locus of Control, Sifat Machiavellian dan Pelatihan Auditor Sebagai Anteseden Perilaku Disfungsional Auditor. E-Jurnal Akuntansi Universitas Udayana, 18(3), 2318-2345.

Dewi, N. M. N. ., \& Wirasedana, I. W. P. (2015). Pengaruh Time Budget Pressure, LOC dan Task Complexity pada Dysfunctional Audit Behavior Akuntan Publik. E-Jurnal Akuntansi Universitas Udayana, 11(1), 1-14.

DeZoort, F. T., \& Lord, A. T. (1997). A Review and Systhesis of Pressure Effectst Research in Accounting. Journal of Accounting Literature, 16, 26-28.

Donelly, D. P., Jeffrey, J. Q., \& David, O. (2003). Auditor Acceptance of Dysfunctional Audit Behavior: An Explanatory Model Using Auditors' Personal Characteristics. Journal of Behavioral Research in Accounting, 15, 87-107.

Dougall, W. M. (1999). An Introduction to Social Psychology. Methuen: London Barnes and Noble.

Ervinayanti, Y. (2013). Pengaruh Time Budget Pressure dan Time Deadline Pressure Terhadap Kinerja Auditor. Universitas Airlangga, Surabaya.

Grahita, D. L. D., \& Sukirman. (2017). The Analysis of Auditor's Personal Charateristic Influence on The Acceptance of Audit Dysfunctional Behaviour. Accounting Analysis Journal, 6(1), 104-110.

Jamilah, S., F., Z., \& C., G. (2007). Pengaruh Gender, Tekanan Ketaatan, dan Kompleksitas Tugas Terhadap Audit Judgement. Simposium Nasional Akuntansi X Makassar, 26 - 28 Juli 2007.

Kumparan. (2018). Hasil Audit BPKP Kalsel Diduga Bermasalah. Retrieved from https://kumparan.com/waduh-hasil-audit-bpkp-kalsel-diduga-bermasalah.

Kustinah, S. (2013). The Influence of Dysfunctional Behavior and Individual Culture on Audit Quality. International Journal of Scientific \& Technology 
Research, 2(5), 118-125.

Limawan, Y. F., \& Mimba, N. P. S. H. (2016). Pengaruh Komitmen Organisasi, Locus of Control dan Tekanan Anggaran Waktu Audit Pada Penerimaan Underreporting of Time. E-Jurnal Akuntansi Universitas Udayana, 15(1), 799-831.

Malone, C. F., \& Roberts, R. W. (1996). Factors Associated with the Incidence of Reduced Audit Quality Behaviors. A Journal of Practice and Theory.

Margheim, L., \& Kelley, T. D. P. (2005). An Empirical Analysis of The Effects of Auditor Time Budget Pressure and Time Deadline Pressure. The Journal Od Applied Business Research-Winter, 21(1).

Mindarti, C. ., \& Elen, P. (2014). The Role of Organizational Commitment on Individual Characteristics that Influence of Auditor Acceptance of Dysfunctional Audit Behavior. International Journal of Business, Economics and Law, 5(1).

Murtapa, \& Budiartha, I. . (2017). Analisis Pengaruh Kompetensi, Independensi, dan Etik pada Kualitas Audit di Perwakilan Badan Pengawasan Keuangan dan Pembangunan (BPKP) Provinsi Bali. E-Jurnal Akuntansi Universitas Udayana, 20(3), 2103-2130.

Mustikayani, N. L. P. D. (2016). Budaya Tri Hita Karana Sebagai Pemoderasi Kompleksitas Tugas dan Tekanan Waktu Terhadap Kinerja Auditor (Studi Empiris pada Kantor Akuntan Publik di Bali). Fakultas Ekonomi dan Bisnis Universitas Udayana, Bali.

Nehme, R., Mutawa., A. Al, \& Jizi, M. (2016). Dysfunctional Behavior of External Auditors The Collision of Time Budget and Time Deadline Evidence from a Developing Country. The Journal of Developing Areas, 50(1), 373-388. https://doi.org/10.1353/jda.2016.0003

Okezone. (2013). Audit BPKP di Kasus Indosat-IM2 Cacat Hukum. Retrieved from https://economy.okezone.com/read/2013/05/01/audit-bpkp-di-kasusindosat-im2-cacat-hukum. $\% 0 \mathrm{~A} \% 0 \mathrm{~A}$

Otley, D. T., \& Pierce, B. J. (1996). Auditor time budget pressure: consequences and antecedents. Accounting, Auditing \& Accountability Journal. https://doi.org/10.1108/09513579610109969

Porter, L. W., Steers, R. M., R.T. Mowday, \&, \& Boulian., P. V. (1974). Organizational Commitment, Job Satisfaction, and Turn Over Among Psyatric Tehnicians. Journal of Applied Psychology, 59, 603-609. 
Prasita, A. \& Priyo, A. (2007). Pengaruh Kompleksitas Audit dan Tekanan Anggaran dan Waktu Terhadap Kualitas Audit dengan Moderasi Pemahaman Terhadap Sistem Informasi. Fakultas Ekonomi, Universitas Kristen Satya Wacana.

Putri, F. P. (2015). Pengaruh Pengetahuan Auditor, Pengalaman Auditor, Kompleksitas Tugas, Locus of Control, dan Tekanan Ketaatan Terhadap Audit Judgment (Studi Kasus pada Perwakilan BPKP Provinsi Riau). Jurnal Online Mahasiswa Fakultas Ekonomi Universitas Riau, 2(2), 1-15.

Restuningdiah, N., \& Indriantoro. (2000). Pengaruh Partisipasi terhadap Kepuasan Pemakai dalam pengembangan Sistem Informasi dengan Kompleksitas Tugas, Kompleksitas Sistem, dan Pengaruh Pemakai sebagai Moderating Variable. Jurnal Riset Akuntansi Indonesia, 3(2), 119-133.

Robbins, S. P. (2003). Organizational Behavior: Concept, Controversies, Application (Seventh Ed). New Jersey: Prentice Hall Inc.

Srimindarti, C. (2012). Penerimaan Auditor Terhadap URT. Jurnal Staf Pengajar Prodi Akuntansi Fakultas Ekonomi, Semarang.

Sugiyono. (2016). Metode Penelitian Kuantitatif, Kualitatif, dan R\&D. Bandung: Alfabeta.

Surya, L. P. L. S., Dwirandra, A. A. N. B., \& Dharma Suputra, I. D. G. (2017). Komitmen Organisasi Memoderasi Pengaruh Kompleksitas Tugas Pada Audit Judgement. E-Jurnal Ekonomi dan Bisnis Universitas Udayana, 5(6), 1909-1938.

Svanström, T. (2016). Time pressure, Training Activities and Dysfunctional Auditor Behavior : Evidence from Small Audit Firms. International Journal of Auditing, 20(1), 42-51.

Umar, M., Megawati, S., Surya, R. L., Shauki, E. R., \& Diyanti, V. (2017). Pressure, Dysfunctional Behavior, Fraud Detection and Role of Information Technology in the Audit Process. Australasian Accounting, Business and Finance Journal, 11(4), 102-115. https://doi.org/10.14453/aabfj.v11i4.8

Winanda, H. I. K., \& Wirasedana, P. I. . (2017). Pengaruh Tekanan Anggaran Waktu, Sifat Machiavellian dan Kompleksitas Tugas Terhadap Perilaku Audit Disfungsional. E-Jurnal Akuntansi Universitas Udayana, 18(1), 500528.

Yolanda, S. (2014). Pengaruh Locus of Control, Keahlian Auditor, Komitmen Organisasi Terhadap Perilaku URT (Studi Empiris pada KAP Pekanbaru \& Padang). Jurnal Akuntansi Riau, 1(2). 
Ida Ayu Widya Krisna Dewi dan I.D.G. Dharma Suputra. Pengaruh ...

Zuhra, I. N. (2009). Locus of Control, Time Budget Pressure dan Penyimpangan Perilaku dalam Audit. Jurnal Telaah dan Riset Akuntansi, 2(2), 104-116. 